\title{
Tuning the catalytic behavior of metal nanoparticles: The issue of the crystal phase
}

\author{
Shuang Liu, Yong Li \#, Wenjie Shen*
}

\section{Introduction}

Metal nanoparticles with the size of 1-10 nm have been widely applied to catalyze chemical reactions in the petrochemical and fine chemical industries, energy processes, and environmental protection. The general characteristics of these solid catalysts are that the coordinatively unsaturated atoms on their surface act as the active sites and the surface electronic properties and geometrical structure determine the catalytic activity, selectivity, and stability [1-6]. The microstructure of metal nanoparticles is usually given in terms of size, morphology, and crystal phase. The size and morphology effect of metal nanoparticles have been extensively studied [7-16]. However, the impact of the crystal phase was rarely considered, mainly because of the facile transformation of metastable crystal phases to thermodynamically stable ones during the synthesis process or under reaction conditions.

Metal nanoparticles usually crystallize in the forms of face-centered cubic $(f c c)$, body-centered cubic $(b c c)$, and hexagonal close-packed ( $h c p$ ) structures as the space packing pattern of the metal atoms. The coordination environment and the spatial distribution of the metal atoms vary significantly in these crystal phases. The atomic coordination number of the $f c c, b c c$ and $h c p$ structures are 12, 8 and 12, respectively, and the corresponding spatial utilization degree of the atoms are $74 \%, 68 \%$ and $74 \%$. For a specific metal nanoparticle, the occupation degree of the surface atoms is also largely determined by the crystal phase [17]. Therefore, changing its crystal phase would change the geometrical structure. This in turn modifies the adsorption and desorption properties of reactants and products. More importantly, the stacking mode of the atoms in different crystal phase also tunes the electronic properties of the metal nanoparticle because the atomic nuclei at the lattice sites provide Coulombic attraction for the valence electrons according to the free electron model [18]. The electronic structure of transition metals near the Fermi level is primarily determined by the $d$ electrons, which significantly affect the adsorption and activation of the reactant molecules as well as their reaction pathway $[19,20]$. A higher energy $d$ state, com- pared to the Fermi energy, gives a stronger interaction with the adsorbed substrate. Cobalt, for example, has three polymorphs, namely, the $h c p, f c c$ and primitive cubic phases ( $\varepsilon$ phase) (Fig. 1) $[21,22]$. The hcp phase is more stable at room temperature, while the $f c c$ and $\varepsilon$ phases are metastable and are transformed into the $h c p$ phase at elevated temperatures $[22,23]$. The Fermi energy of the $h c p, f c c$ and $\varepsilon$ phases are $5.49,5.29$, and $5.15 \mathrm{eV}$, respectively [23]. The electron density around the Fermi level follows the order of $f c c$-Co $<\varepsilon$-Co $<h c p$-Co. The electron localization function of $h c p$-Co is a radial electron distribution, while $f c c$-Co electron distribution has an evident polarization. The density of states (DOS) for the $d$ band in $\varepsilon$-Co is broader than in the others. Therefore, it is expected that tuning the crystal phase of cobalt nanoparticles would change their geometric environment and electronic property, and in turn the catalytic performance $[23,24]$.

Nanoalloys consist of two or more types of metals and present different electronic structures compared with the individual metals [25-28]. This allows tuning their electronic structure and catalytic properties more efficiently [29-31]. For instance, the $d$ state of the $\mathrm{AuCu}$ alloy varies considerably between $\mathrm{Au}$ and $\mathrm{Cu}$ (Fig. 2), depending on the molar ratio of $\mathrm{Au}$ and $\mathrm{Cu}$ [32]. $\mathrm{Au}_{3} \mathrm{Cu}$ nanoparticles with an $f c c$ structure showed a much higher activity for the electrochemical reduction of $\mathrm{CO}_{2}$ than the other compositions. Nickel particles are traditionally used to catalyze $\mathrm{CO}_{2}$ hydrogenation to methane, but alloyed $\mathrm{Ni}_{5} \mathrm{Ga}_{3}$ particles catalyzed $\mathrm{CO}_{2}$ hydrogenation to methanol with a comparable activity to industrial $\mathrm{Cu} / \mathrm{Zn} / \mathrm{Al}_{2} \mathrm{O}_{3}$ catalysts [33]. The $\mathrm{Al}_{13} \mathrm{Fe}_{4}$ alloy exhibited a similar activity to commercial $\mathrm{Pd}$

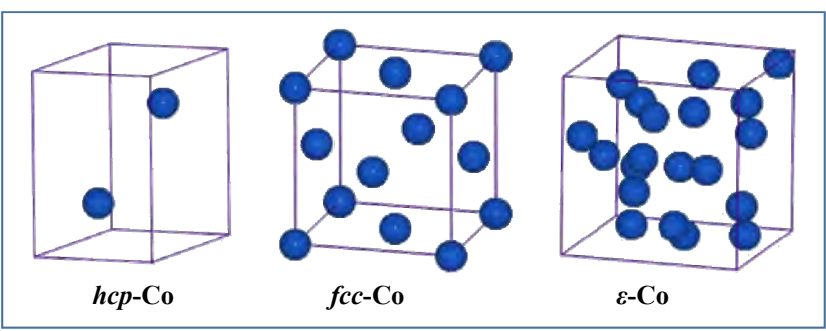

Fig. 1. Crystal structures of $h c p$-Co, $f c c$-Co and $\varepsilon$-Co. 


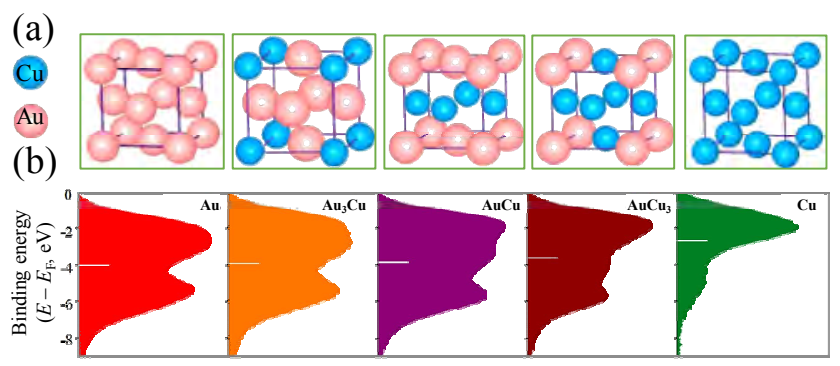

Fig. 2. Crystal lattices (a) and surface valence band photoemission spectra (b) of $\mathrm{Au}, \mathrm{Cu}$ and their alloys. Reprinted with permission from Ref. [32]. Copyright 2014, Macmillan Publishers Limited.

catalysts for the semi-hydrogenation of acetylene [34]. The AgCo alloy gave a comparable activity to Pt nanoparticles for electrochemical oxygen reduction [35]. These examples are convincing evidence that tuning the electronic structure of metal nanoalloys can improve the catalytic activity and mediate the reaction route. Moreover, metal alloys crystallize in versatile crystal phases through the flexible hybrid pathways of $d$ electrons from the component metals, providing more options for mediating the electronic properties [26,36]. For example, $\mathrm{Pt}$ and Fe typically crystallize in the $f c c$ and $b c c$ phases, respectively, but alloyed FePt particles may be $f c c$-Fes $\mathrm{Pt}$, $f c c$-FePt 3 or FePt with a face-centered tetragonal $(f c t, L 10)$ structure [37]. As shown in Fig. 3, the disordered $F m \overline{3} m$ and ordered $P m \overline{3} m$ structures of $\mathrm{Cu}_{60} \mathrm{Pd}_{40}$ alloy had dramatically different DOS [38]. The ordered phase gave a lower DOS than the disordered one, showing a higher degree of covalent bonding. As a result, the ordered crystal phase enhanced ethylene selectivity up to $90 \%$ in the semi-hydrogenation of acetylene.

In this perspective, we summarize recent progress on the crystal phase effect of metal nanoparticles in nanocatalysis. We first briefly introduce the principle of crystal phase controlled synthesis of metal nanoparticles and then examine the effect of the crystal phase of the metal and alloy nanoparticles on their catalytic performance. Finally, we present our perspectives on the future development of the crystal phase effect of metal nanoparticles, which is a challenging topic in nanocatalysis.
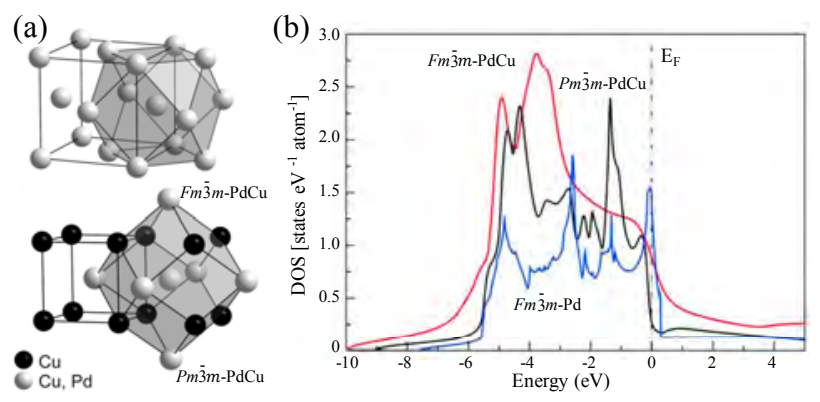

Fig. 3. Crystal structures of disordered $\mathrm{PdCu}(F m \overline{3} m)$ and ordered $\mathrm{PdCu}$ (Pm3m) (a) and their DOS (b). Reprinted with permission from Ref. [38] Copyright 2013, MDPI Publishing.

\section{Crystal phase-controlled synthesis of metals}

Metal atoms usually pack in the structure of an appropriate space group to decrease the surface energy to be as low as possible and thus form the most stable crystal phase. This means that mediating the crystal phase of metal nanoparticles requires modifying their surface energy during the synthesis process. Both theoretical calculations and experimental studies have confirmed that the control of crystal phase of metal particles strongly depends on controlling the size and morphology $[39,40]$. For example, Co nanoparticles favor an $f c c$ phase as twinned icosahedrons at sizes of less than $20 \mathrm{~nm}$, whereas they are present as a hcp structure in the form of polyhedrons at sizes of more than $110 \mathrm{~nm}$ [39]. This is because of the different atom density in the exposed crystal faces induced by the surface energy. The phase transition of PtCo nanoparticles was strongly correlated with their size and morphology [40]. Bulk PtCo alloy transforms from disordered $f c c$ to ordered $L 10$ at $1098 \mathrm{~K}$, whereas the $2.4-3 \mathrm{~nm}$ sized particles complete the phase transition at 773-923 K. Moreover, this transformation did not require the size of the PtCo nanoparticles to be less than $3 \mathrm{~nm}$ for the three axes; only one axial size smaller than the critical value would facilitate the phase transition at lower temperature. This implies that the phase transformation is also linked to the morphology and the metastable crystal phase can be obtained by tuning the shape of the metal nanoparticles as

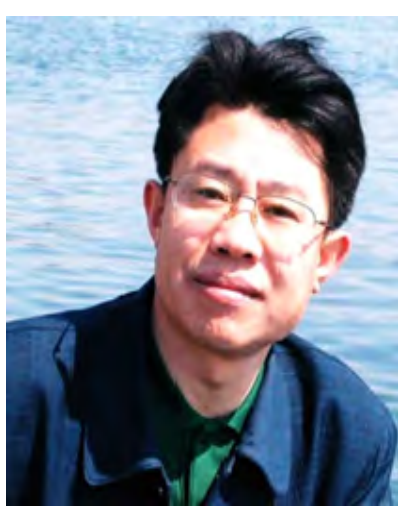

Wenjie Shen (Dalian Institute of Chemical Physics, Chinese Academy of Science) received the Catalysis Award for Young Scientists of The Catalysis Society of China and National Natural Science Fund for Distinguished Young Scholars in 2010. Professor Wenjie Shen received his PhD from the Institute of Coal Chemistry, Chinese Academy of Sciences in 1995. From 1996 to 1998, he was a postdoctor in Korea Research Institute of Chemical Technology. During 1998-2001, he worked, as an NEDO Research Fellow, at Kansai Research Center of National Institute of Advanced Industrial Sciences and Technology (AIST), Japan. In 2001 he was awarded the "Hundred Talents Program" from the Chinese Academy of Sciences and joined the State Key Laboratory of Catalysis (SKLC) of Dalian Institute of Chemical Physics, Chinese Academy of Sciences. Currently, his research interests include (1) Synthesis of catalyst particles with controllable size and shape, including metals and metal oxides; (2) Analyses on the dynamic behavior of catalytic materials under or close to reaction conditions; (3) Applications of nanocatalysts to chemical reactions relevant to energy and environmental aspects. He has published more than 140 peer-reviewed papers with over 4500 citations. 
well.

To date, the crystal phase control of metal nanoparticles has been achieved by two approaches: liquid phase reduction and solid phase conversion. The synthesis of metal nanoparticles in liquid solution is initialized by the chemical reduction or thermal decomposition of a metal precursor. The generated metal atom then aggregates into nuclei after reaching a degree of supersaturation [41-47]. The growth pattern of the metal particles is a balance of thermodynamics and kinetics. Accordingly, the systematic manipulation of synthesis parameters, especially the use of suitable surfactants, is the most effective strategy to tune the surface energy of the growing metal particle and its crystal phase. For example, reduction of $\mathrm{RuCl}_{3}$ by ethylene glycol (EG) with the presence of poly(N-vinyl-2-pyrrolidone) at $473 \mathrm{~K}$ yielded $h c p$-Ru nanoparticles of 2-5 nm (Fig. 4). However, when the metal precursor and the solvent were replaced by $\mathrm{Ru}(\mathrm{acac})_{3}$ and triethylene glycol, respectively, $f c c$-Ru nanoparticles with similar sizes were produced [48]. Reduction of $\mathrm{RuCl}_{3}$ in ethanol by $\mathrm{NaBH}_{4}$ at room temperature produced $f c c-\mathrm{Ru}$ particles of $2.2 \mathrm{~nm}$ in size [49]. The control of particle size and crystal structure was achieved by adjusting the reduction rate of the ruthenium ion in the liquid phase and simultaneously using a surfactant to stabilize the metastable phases. Thermal decomposition of $\mathrm{Co}_{2}(\mathrm{CO})_{8}$ in 1,2-dichlorobenzene with the presence of oleic acid and trioctylphosphine oxides yielded $\varepsilon$-Co particles of $8.7 \mathrm{~nm}$ (Fig. 5), while $f c c$-Co nanoparticles with a similar size $(8.0 \mathrm{~nm})$ was produced in dodecane with the aid of oleic acid and dioctylamine [50]. This result demonstrated
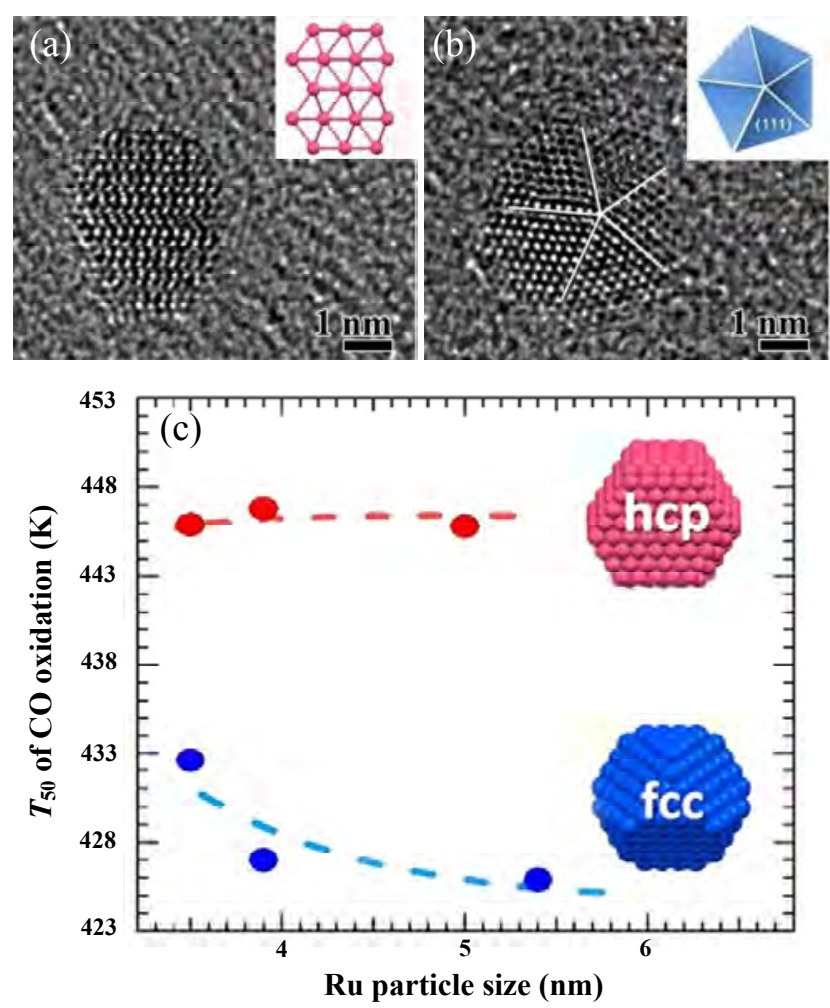

Fig. 4. TEM images of $h c p-\mathrm{Ru}(\mathrm{a})$ and $f_{c c}$-Ru nanoparticles (b), and their catalytic performance for $\mathrm{CO}$ oxidation (c). Reprinted with permission from Ref. [48]. Copyright 2013, American Chemical Society.

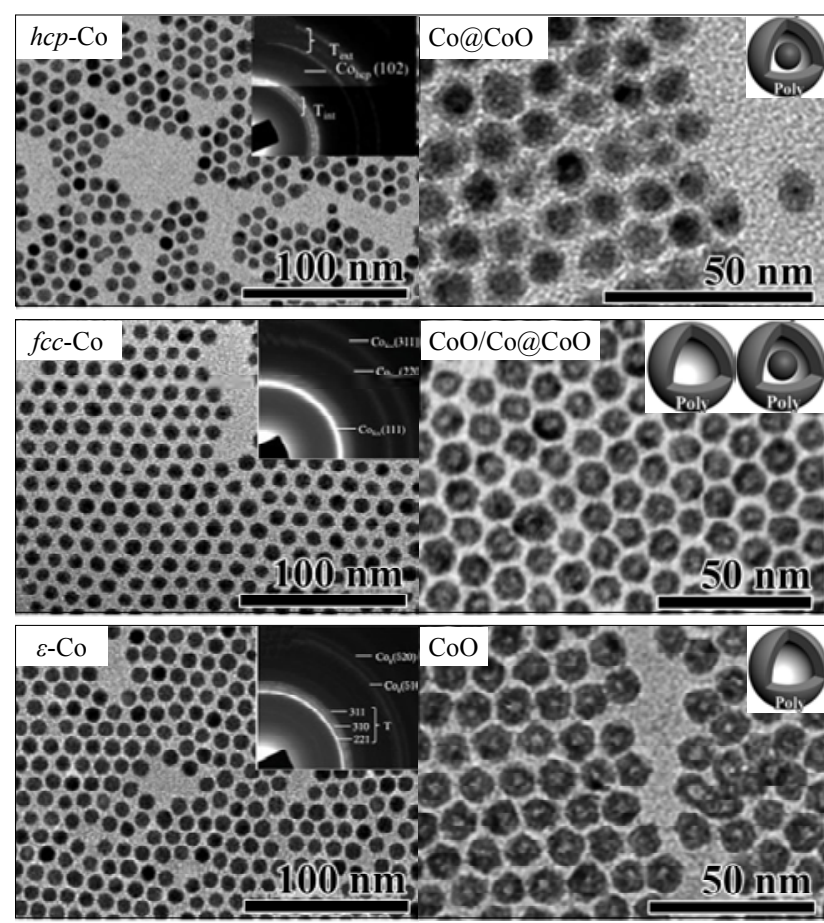

Fig. 5. TEM images of $h c p$-Co, $f c c$-Co and $\varepsilon$-Co nanoparticles and their oxides on heating at $493 \mathrm{~K}$ under oxygen. Reprinted with permission from Ref. [50]. Copyright 2015, WILEY-VCH Verlag GmbH \& Co.

that the surfactant mediated the crystal phase of the metal nanoparticles through effectively lowering the surface energy upon adsorption.

In addition, metal nanoparticles with a specific crystal phase were also used as the seed or crystallite nuclei, based on its inherent structural symmetry, to direct the growth of metal nanoparticles with a desired crystal phase [51,52]. Applying $f c c-\mathrm{AuCu}$ nanoparticles of $10.2 \mathrm{~nm}$ as the seed, the thermal decomposition of $\mathrm{Co}_{2}(\mathrm{CO})_{8}$ and $\mathrm{Fe}(\mathrm{CO})_{5}$ at $503 \mathrm{~K}$ generated a $\mathrm{AuCu} @ \mathrm{FeCo}$ core-shell structure (Fig. 6), where FeCo crystallized as the $b c c$ phase [53]. Annealing of the composite at $653 \mathrm{~K}$ caused the FeCo shell to transform into the body-centered tetragonal $(b c t)$ phase while the $\mathrm{AuCu}$ core converted into the $L 1_{0}$ phase [54]. This transformation was driven by the lattice match of the core and shell layers, which induced a heteroepitaxial growth of the FeCo shell.

Solid phase conversion is another route to mediate the crystal phase of the metal nanoparticles. It typically involves the thermal treatment of metal nanoparticles that are in the conventional crystal phase at elevated temperature and under a proper atmosphere. It is worth noting that this method differs from the traditional metallurgy process that is usually performed at temperatures above the melting point of metals. A solid phase conversion is conducted at much milder conditions by taking advantage of the chemical interaction of the reactive gases, mainly $\mathrm{H}_{2}$ or $\mathrm{CO}$, with the metal nanoparticles [55-57]. For example, $f c c-\mathrm{AuCu}$ nanoparticles of $3.4 \mathrm{~nm}$ were transformed into the ordered $L 10$ phase under a $\mathrm{H}_{2}$ atmosphere above $433 \mathrm{~K}$ (Fig. 7) [58]. Molecular hydrogen induced the generation of lattice strain and possible charge transfer between $\mathrm{Au}$ and $\mathrm{Cu}$, which facilitated the phase transformation 
(a)

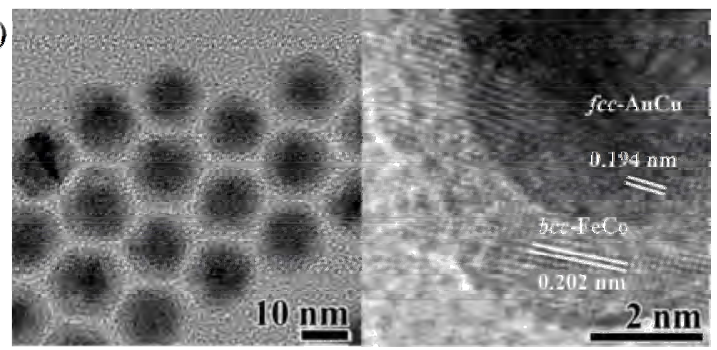

(b)

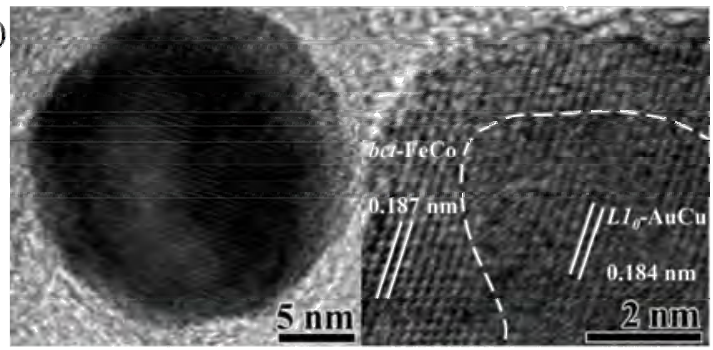

(c)

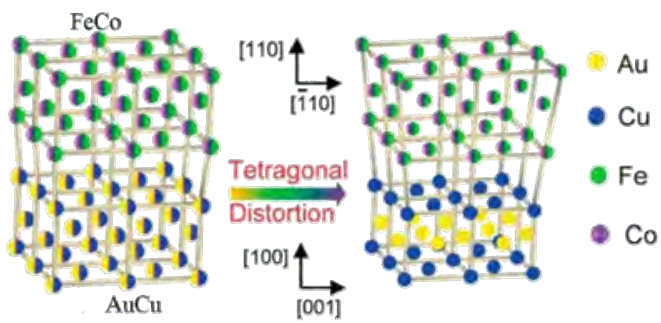

Fig. 6. TEM images of $f c c-\mathrm{AuCu} @ b c c-\mathrm{FeCo}$ nanoparticles (a) and L10-AuCu@bct-FeCo nanoparticles (b); Illustration of the heteroepitaxial interfacial structure of the AuCu@FeCo core-shell nanostructure (c). Reprinted with permission from Ref. [54]. Copyright 2014, American Chemical Society.

(a)
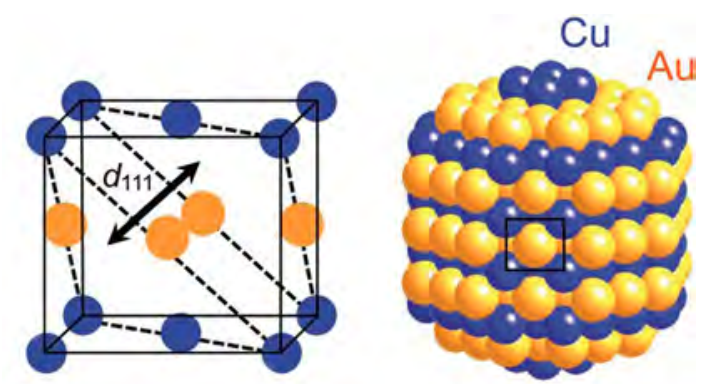

(b)

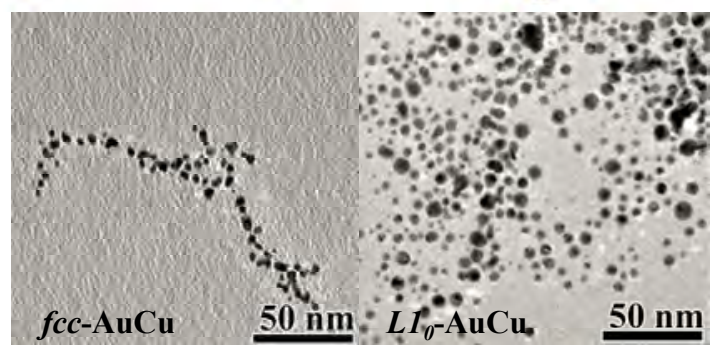

Fig. 7. Element arrangements in the ordered $L 1_{0}$ lattice of the $\mathrm{AuCu}$ nanoalloy (a) and TEM images of $f c c-\mathrm{AuCu}$ and $L 1_{0}$-AuCu nanoparticles (b). Reprinted with permission from Ref. [58]. Copyright 2014, The Royal Society of Chemistry.

under such a mild condition. Similarly, treating fcc-AuPdCo nanoparticles at $1073 \mathrm{~K}$ in $\mathrm{H}_{2}$ produced a mixed system consisting of primitive trigonal, rhombohedral, and face-centered cubic phases [59]. Treatment of disordered $f c c-\mathrm{Pt}_{3} \mathrm{Co}$ nanopar- ticles at $973 \mathrm{~K}$ in $\mathrm{H}_{2}$ produced the ordered $\mathrm{L1}_{2}$ intermetallic structure [60]. More interestingly, CO exerted a promotional effect on the phase transformation of metal nanoparticles through a carbonization process. Fcc-Co nanoparticles of $7 \mathrm{~nm}$ in a $25 \mathrm{wt} \% \mathrm{Co}-0.1 \% \mathrm{Pt} / \mathrm{Al}_{2} \mathrm{O}_{3}$ sample that experienced hydrogen at $623 \mathrm{~K}$ were converted into hcp-Co nanoparticles of $9 \mathrm{~nm}$ after a successive treatment in flowing $\mathrm{CO}$ and $\mathrm{H}_{2}$ at $623 \mathrm{~K}$ (Fig. 8) [61,62]. In situ XRD measurement of this phase conversion process confirmed that the interaction of $f c c$-Co nanoparticles with $\mathrm{CO}$ formed cobalt carbides, which were finally evolved into hcp-Co nanoparticles by $\mathrm{H}_{2}$ reduction.

\section{Metal nanoparticles}

Cobalt nanoparticles are typically used to catalyze Fischer-Tropsch synthesis (FTS) to convert syngas into hydrocarbons. Cobalt particles undergo chemical and structural evolution during the pretreatment and reaction, and the overall catalytic performance relies on the size of the resulting cobalt particles [63-66]. One interesting observation was that the reaction becomes structure insensitive when the cobalt particles are larger than $6 \mathrm{~nm}[67,68]$. This remarkable size effect was ascribed to the enhanced proportion of low coordinated surface sites on small Co particles ( $<6 \mathrm{~nm}$ ), which favored a higher coverage of irreversibly bonded CO. Surface studies have indentified that $\mathrm{CO}$ dissociation on the zigzag grooved (1120) facet proceeds faster than that on the close-packed (0001) facet. More importantly, the chain growth probability on the former $(0.36$ at $523 \mathrm{~K})$ is larger than that on the latter
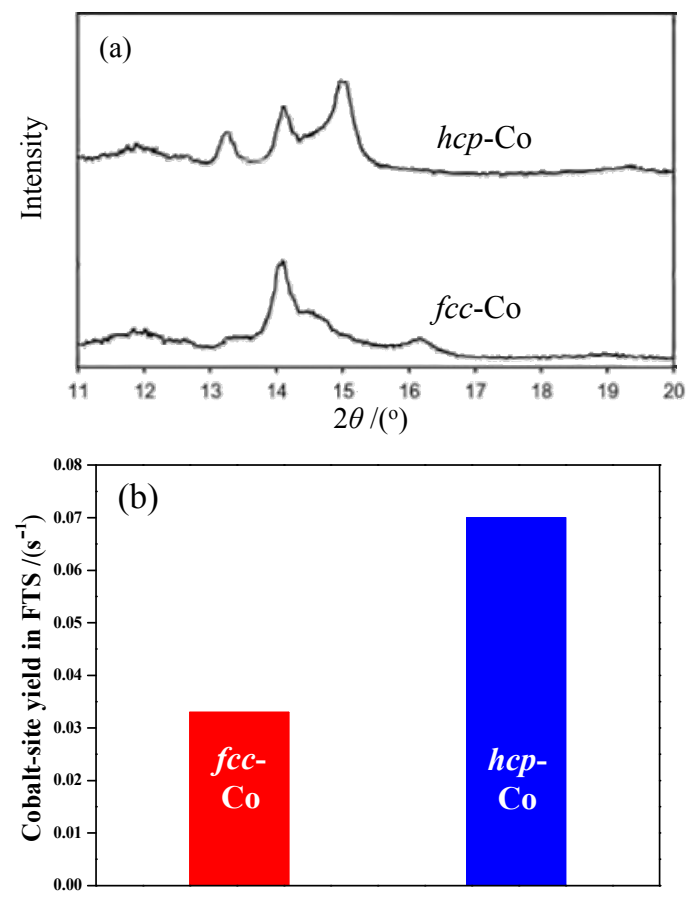

Fig. 8. XRD patterns of $f c c$-Co and $h c p$-Co nanoparticles in $\mathrm{CoPt} / \mathrm{Al}_{2} \mathrm{O}_{3}$ catalysts (a) and their activity in FTS (b). Reprinted with permission from Ref. [62]. Copyright 2011, Elsevier. 
(0.20 at $523 \mathrm{~K})$ [69].

The crystal phase transition of cobalt nanoparticles in practical catalysts, mainly achieved through the initial carbonization by $\mathrm{CO}$ and the subsequent $\mathrm{H}_{2}$ reduction, also played a vital role in determining the performance in FTS. For example, the reaction rate and product distribution of $23 \mathrm{wt} \% \mathrm{Co}-0.05$ wt $\% \mathrm{Pt} / \mathrm{Al}_{2} \mathrm{O}_{3}$ catalysts clearly showed a crystal phase dependent effect. Under the same reaction conditions, $h c p$-Co nanoparticles provided a space time yield of $4.29 \times 10^{-5} \mathrm{~mol} \mathrm{co} /\left(\mathrm{gco}_{0}\right.$. s) and a $\mathrm{C}_{5+}$ selectivity of $94.1 \%$, whereas $f_{c c}$-Co particles showed a lower reaction rate of $3.55 \times 10^{-5} \mathrm{~mol} \mathrm{co} /\left(\mathrm{g}_{\mathrm{Co}} \cdot \mathrm{s}\right)$ with a $\mathrm{C}_{5}$ selectivity of $89.3 \%$ [70]. Similarly, with $25 \mathrm{wt} \%$ Co-0.1 wt $\% \mathrm{Pt} / \mathrm{Al}_{2} \mathrm{O}_{3}$ catalysts, the time yield of $h c p$-Co nanoparticles $(9 \mathrm{~nm})$ was two times that of $f c c$-Co nanoparticles $(7 \mathrm{~nm})$ (Fig. 8) $[61,62]$. The turnover frequency (TOF) of $h c p$-Co particles $(12.0 \mathrm{~nm})$ in a $10 \mathrm{wt} \% \mathrm{Co} / \mathrm{ZrO}_{2}$ catalyst approached $0.054 \mathrm{~s}^{-1}$, being much larger than that of $f c c$-Co nanoparticles of $12.4 \mathrm{~nm}$ $\left(0.033 \mathrm{~s}^{-1}\right)$ [71]. The superior performance of $h c p$-Co particles, in terms of activity and $\mathrm{C}_{5+}$ selectivity, was further shown with $20 \mathrm{wt} \% \mathrm{Co} / \mathrm{SiO}_{2}$ catalysts [72]. The presence of surface defects and stacking faults on $h c p$-Co nanoparticles facilitated the inner layer diffusion of carbide from the surface to bulk and thus promoted CO activation [73]. Recent theoretical calculations further verified the promotional mechanism of $h c p$-Co nanoparticles in FTS [74]. According to the principle of Wulff construction, $h c p$-Co nanoparticles preferentially expose the (1011) and (1010) facets (Fig. 9). The former surface is richened with the B5-type site, an ensemble of four atoms of the surface and a fifth atom in the subsurface, which is the active center for CO dissociation and carbon chain growth [75-77]. Fcc-Co nanoparticles, however, were mainly enclosed by the close-packed (111) facet that is much less active for CO dissoci-

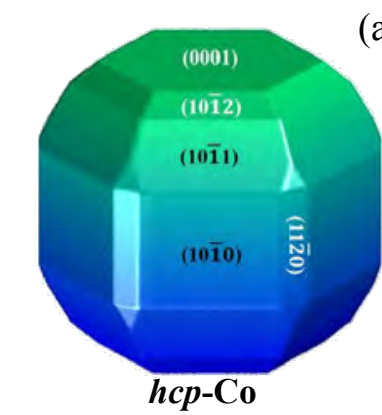

(a)

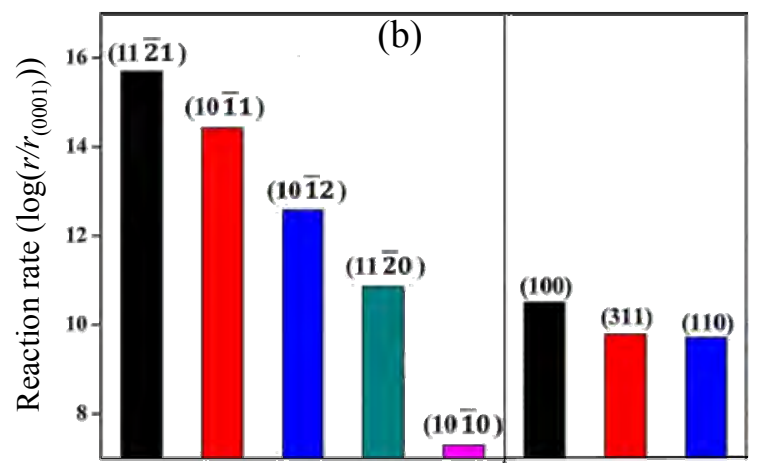

Fig. 9. Wulff constructions of $h c p$-Co and $f c c$-Co (a) and their reaction rates for CO dissociation (b). Reprinted with permission from Ref. [74]. Copyright 2013, American Chemical Society. ation.

However, a recent example showed the higher activity of $f c c$-Co nanoparticles in $20 \mathrm{wt} \% \mathrm{Co} / \mathrm{SiO}_{2}$ catalysts for FTS [78]. Calcination at $823 \mathrm{~K}$ and successive $\mathrm{H}_{2}$ reduction at $673 \mathrm{~K}$ of the catalyst precursor yielded mainly $h c p$-Co nanoparticles of 31.2 $\mathrm{nm}$ while direct reduction by $\mathrm{H}_{2}$ at $673 \mathrm{~K}$ predominately formed $f c c$-Co nanoparticles of $16.4 \mathrm{~nm}$. The TOF of $f c c$-Co was $48.2 \times 10^{-3} \mathrm{~s}^{-1}$ but it was $18.0 \times 10^{-3} \mathrm{~s}^{-1}$ for $h c p$-Co nanoparticles, clearly demonstrating the importance of the crystal phase of the cobalt nanoparticles. The large hcp-Co particles showed a more regular surface with a prevalence of planar sites, while the smaller $f c c$-Co particle gave a higher fraction of coordinatively unsaturated sites. Therefore, the crystal phase effect of cobalt nanoparticles in FTS may be related to the chemical state, particle size, crystal facets exposed, and more importantly the dynamic change of the catalyst particles under reaction conditions. Nevertheless, these experimental results have identified that tuning the crystal phase of the cobalt nanoparticles, in conjunction with the size and morphology effects, provides a potential way to develop highly efficient FTS catalysts.

The crystal phase of cobalt nanoparticles also affects their surface rearrangement under FTS conditions as well as their oxidation to cobalt oxides under $\mathrm{O}_{2}$ atmosphere. During FTS, $\mathrm{CO}$ activation and dissociation induced the surface reconstruction of the Co particles [66,79]. The mostly exposed (111) facet of $f c c$-Co was reconstructed to the (100) plane [79], which has more uncoordinated atoms that are highly active for FTS [80]. The close-packed (0001) facet on hcp-Co was kept almost unchanged and only the stepped (1012) facet experienced surface rearrangement to push Co rows apart in the [010] direction [81]. The oxidation of cobalt nanoparticles generally follows the Kirkendall process, which is determined by the mutual diffusion rates of cobalt and oxygen anions [82]. Oxidation of $h c p$-Co, $\varepsilon$-Co and fcc-Co nanoparticles (with a similar size of 8 $\mathrm{nm})$ at $473 \mathrm{~K}$ formed a core-shell Co@CoO nanostructure, CoO hollow nanoparticle, and a mixture of hollow $\mathrm{CoO}$ and yolk-shell Co@CoO, respectively (Fig. 5) [50,83]. This was attributed to the different stacking patterns of the cobalt atoms in these crystal phases, which influenced the rates of Kirkendall diffusion and cobalt oxide construction.

Iron nanoparticles are the active component in catalysts for ammonia synthesis and FTS [84,85]. The crystal phase of Fe particles determines the activation of $\mathrm{N}_{2}$ and $\mathrm{CO}$ molecules. The activation of $\mathrm{N}_{2}$ on the Fe surface includes the initial dissociative adsorption and the subsequent formation of the nitride phase. The total nitrogen uptake on $f_{c c}$-Fe is higher than that on $b c c$-Fe [86]. In the case of $\mathrm{CO}$ activation, $b c c$-Fe dissociates $\mathrm{CO}$ at $300 \mathrm{~K}$, whereas the $f c c$ phase only provides weak adsorption of CO (Fig. 10) [87]. This is due to the different adsorption geometry of $\mathrm{CO}$ on these phases. The smaller distance of the iron atoms $(0.29 \mathrm{~nm})$ and the fourfold hollow site on bcc-Fe facilitates $\mathrm{CO}$ adsorption through its $\pi$ orbital, but the relatively larger distance of the atoms $(0.34 \mathrm{~nm})$ on $f c c$-Fe is too large to provide the necessary active site. A similar observation was $\mathrm{Fe}(\mathrm{CO})_{5}$ decomposition on iron surfaces [88]. $\mathrm{Fe}(\mathrm{CO})_{5}$ was dissociative activated on $b c c$-Fe but only molecularly adsorbed on $f c c$-Fe. All these studies on model samples suggested the im- 


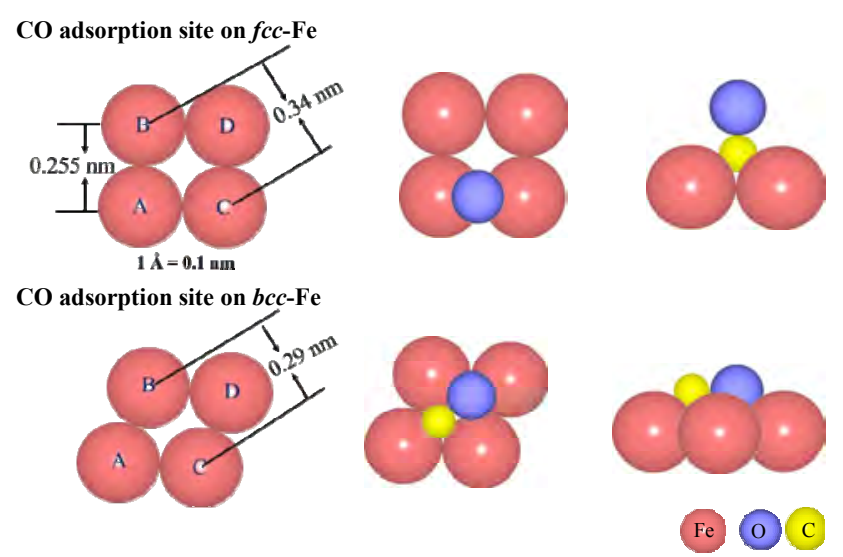

Fig. 10. $\mathrm{CO}$ adsorption geometry on $f c c$-Fe and $b c c$-Fe, where the distance between $\mathrm{Fe}(\mathrm{B})$ and $\mathrm{Fe}(\mathrm{C})$ is the decisive factor. Reprinted with permission from Ref. [87]. Copyright 1996, Elsevier.

portance of the iron crystal phase in the activation of $\mathrm{N}_{2}$ and $\mathrm{CO}$ molecules and are helpful in designing and preparing highly efficient catalysts for ammonia synthesis and FTS.

Ruthenium nanoparticles effectively catalyze the low temperature synthesis of ammonia [89,90], hydrogenation of benzene to cyclohexene [91], FTS [85,92] and CO oxidation [93]. Ru prefers to adopt a hexagonal close-packed mode because its Gibbs free energy is smaller than that of the face-centered cubic model [94]. With the progress of solution chemistry, metastable $f c c$-Ru nanoparticles have been obtained by precisely modifying the surface energy and the reduction kinetics. An obvious crystal phase effect of $\mathrm{Ru}$ nanoparticles in $\mathrm{Ru} / \mathrm{Al}_{2} \mathrm{O}_{3}$ was observed for $\mathrm{CO}$ oxidation. For $f c c$-Ru nanoparticles (larger than 3 $\mathrm{nm})$, the temperature for $50 \%$ conversion $\left(T_{50}\right)$ of CO was 426 $\mathrm{K}$ (Fig. 4), while the $T_{50}$ for $h c p$-Ru particles was increased to $446 \mathrm{~K}$ [48]. CO oxidation over $\mathrm{Ru}$ is initialized with the oxidation of the $\mathrm{Ru}(001)$ facet and the formed $\mathrm{RuO}_{2}(110)$ layers act as the active sites [95,96]. $f c c$-Ru nanoparticles are enclosed by the (111) facet and present twin boundaries with fivefold symmetry axes, which facilitate the formation of $\mathrm{RuO}_{x}$ active sites and therefore enhanced the catalytic activity. The impact of the crystal phase of $\mathrm{Ru}$ nanoparticles was recently demonstrated in the hydrolysis of ammonia borane. The activation energy over $h c p$-Ru nanoparticles (1.7-2.9 nm) was 33-92 $\mathrm{kJ} / \mathrm{mol}$, but it decreased to $27.5 \mathrm{~kJ} / \mathrm{mol}$ over $f c c$-Ru nanoparticles (2.2 nm) [49]. A similar behavior of the crystal phase was observed over $\mathrm{Ru}$ nanoparticles supported on layered $\mathrm{MgAl}$ oxides for the same reaction. The activation energy over $h c p$ and $f c c$-Ru nanoparticles was 17.7 and $50.2 \mathrm{~kJ} / \mathrm{mol}$, respectively, although both samples have a very similar size of $2.0 \mathrm{~nm}$ [97].

Pallidum nanoparticles are widely used in the hydrogenation of organic substrates. Pd commonly crystallizes as a face -centered cubic structure, but the dissociation of molecular hydrogen into hydrogen atoms isotropically expands its lattice under reaction conditions [98-101]. The formed hydride species transform from the dilute phase of $\mathrm{PdH}_{x}$ to a hydrogen-rich and lattice expanded phase $\left(\beta-\mathrm{PdH}_{x}\right)$ that is characterized with a higher activity for deep hydrogenation. This transformation is governed by the size and morphology of the Pd nanoparticles
$[102,103]$, and further influences their catalytic performance $[104,105]$. In the case of the hydrogen reduction of nitrite to $\mathrm{N}_{2}$ over $\mathrm{Pd} / \gamma \mathrm{Al}_{2} \mathrm{O}_{3}$ catalysts, the activity slightly decreased from 21 $\mathrm{mg}_{\text {nitrite }} /\left(\mathrm{g}_{\text {surface Pd}} \cdot \mathrm{min}\right.$ ) to $16 \mathrm{mgnitrite} /\left(\mathrm{g}_{\text {surface } \mathrm{Pd}} \cdot \mathrm{min}\right)$ as the size of the Pd particles decreased from $10 \mathrm{~nm}$ to $2 \mathrm{~nm}$, but the selectivity to $\mathrm{N}_{2}$ dramatically increased from $85 \%$ to $99 \%$ [106]. The promotion in $\mathrm{N}_{2}$ selectivity was attributed to the fact that the smaller Pd particles prohibited the formation of the $\beta-\mathrm{PdH}_{x}$ species and hence limited the over-hydrogenation of nitrite to $\mathrm{NH}_{3}$. Meanwhile, the strong hydrogenation ability of $\beta-\mathrm{PdH}_{x}$ species has been reported to benefit the hydrodesulfurization of thiophene and benzothiophene over PtPd alloy nanoparticles [107]. Recent theoretical calculations have revealed the chemical mechanism of $\mathrm{PdH}_{x}$ species for ethyl hydrogenation to ethane over Pd nanoparticles (Fig. 11) [108]. When the $\mathrm{Pd}$ surface was saturated by $\mathrm{H}_{2}\left(\mathrm{H}^{\mathrm{ad}}{ }_{78} \mathrm{H}^{\text {sub }}{ }_{0} \mathrm{Pd} \mathrm{d}_{79}\right)$, the rate constant of ethyl hydrogenation to ethane at $298 \mathrm{~K}$ was $5 \times 10^{7} \mathrm{~s}^{-1}$ with the activation energy of $29 \mathrm{~kJ} / \mathrm{mol}$. On further increasing the adsorbed amount of $\mathrm{H}_{2}$ with the formation of subsurface-saturated $\mathrm{H}_{78} \mathrm{H} \mathrm{Hub}_{24} \mathrm{Pd}_{79}$ species, the hydrogenation rate constant was strikingly increased to $8 \times 10^{11} \mathrm{~s}^{-1}$ and the activation energy drastically decreased to only $5 \mathrm{~kJ} / \mathrm{mol}$. This was because the subsurface $\mathrm{H}$ species destabilized adsorbed $\mathrm{H}$ on the surface by changing the electronic structure of the Pd nanoparticles with the occupation of the $\mathrm{H}^{\text {ad}}-\mathrm{Pd}$ anti-bonding orbital. These results convincingly demonstrated that the phase transition of the Pd hydride species should be taken into account when preparing efficient hydrogenation catalysts.

\section{Metal alloy nanoparticles}

Alloyed metal nanoparticles present another strategy to enhance catalytic performance because of their versatile crystal phases. Recent progress in nanomaterials, especially the simultaneous control of size, shape, and crystal phase, provide a solid base for exactly tuning their electronic properties and coordination environment [41-46]. When the crystal phase of

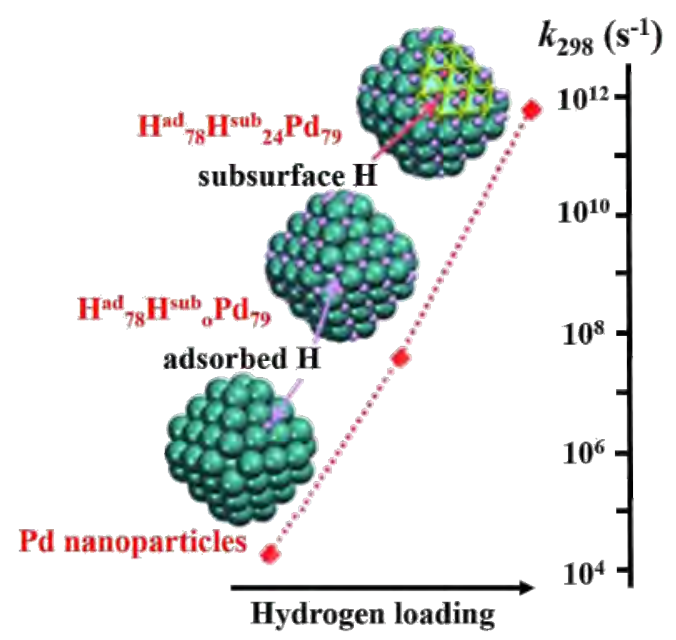

Fig. 11. Influence of adsorbed hydrogen on the rate constant of ethyl hydrogenation at $298 \mathrm{~K}$ over Pd nanoparticles. Reprinted with permission from Ref. [108]. Copyright 2014, WILEY-VCH Verlag GmbH \& Co. 

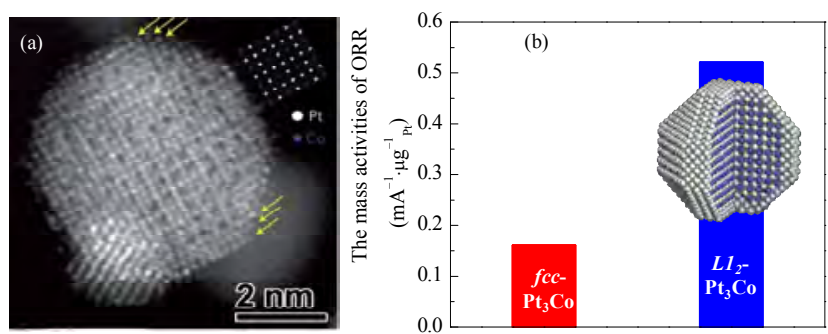

Fig. 12. HAADF-STEM image (a) of a $L 1_{2}-\mathrm{Pt}_{3} \mathrm{Co}$ particle and its catalytic performance for ORR at room temperature (b). Reprinted with permission from Ref. [60]. Copyright 2013, Macmillan Publishers Limited.

$\mathrm{Pt}_{3}$ Co nanoparticles was changed from disordered $f c c$ to ordered $L_{1}$ under a $\mathrm{H}_{2}$ atmosphere, the mass activity for the oxygen reduction reaction (ORR) significantly increased from 0.16 to $0.52 \mathrm{~mA}^{-1} \cdot \mu^{-1} \mathrm{Pt}$ (Fig. 12) [60]. Moreover, the ordered crystal structure also prevented the leaching of Co during the electrochemical reaction. The detailed structural analysis indicated that the phase transformation induced the formation of a Pt rich shell and a stable intermetallic $\mathrm{Pt}_{3} \mathrm{Co}$ core. AuPdCo nanoparticles with a mixture of the $P \overline{3} m, R \overline{3} m$, and $F m \overline{3} m$ phases and a twin lattice structure showed a much higher ORR performance than the pure $F m \overline{3} m$ phase [59]. Hydrogen treatment of FePt@Pt catalysts with a core-shell structure at $923 \mathrm{~K}$ converted the crystallite phase of FePt from $f c c$ to $f c t$. This transformation released the over-compressed surface Pt strain and subsequently enhanced the ORR activity [109]. In the case of the electro-oxidation of ethanol, the activity of PtRhSn nanoparticles in the Niggliite mineral phase was twice that on the $f c c$-PtRhSn alloy because of the better ability in breaking the C-C bond of ethanol [110]. For the electrooxidation of ethanol and formic acid on $\mathrm{ZrPt}_{3}$ nanoparticles, the hexagonal structure showed a superior performance to the $f c c$-phase, even when the former has a large particle size of $200 \mathrm{~nm}$ (Fig. 13). This was assigned to the higher surface energy of hcp-ZrPt ${ }_{3}(1.47$ $\left.\mathrm{J} / \mathrm{m}^{2}\right)$ than that of the $f c c$ phase $\left(1.34 \mathrm{~J} / \mathrm{m}^{2}\right)$ [111]. Similarly, the crystal phase transformation of $\mathrm{Ag}_{3} \mathrm{In}$ nanoparticles from disordered $F m \overline{3} m$ to ordered $P m \overline{3} m$ remarkably enhanced the activity for $p$-nitrophenol reduction by $\mathrm{NaBH}_{4}$ because the ordered structure isolated the active sites [112]. PdRu nanoalloys with a mixture of the $f c c$ and $h c p$ phases catalyzed CO oxidation more effectively than $f c c$-PdRu nanoalloys, simply because of

(a)

(b)
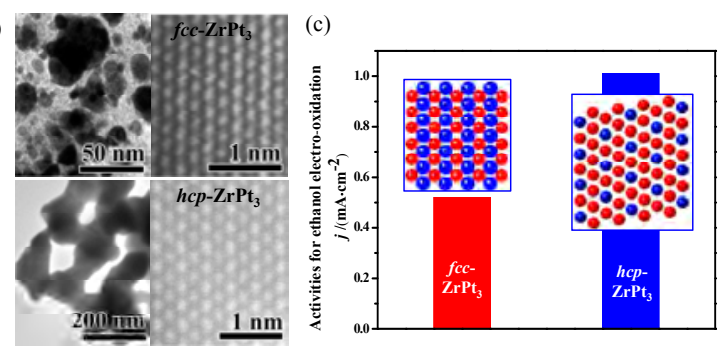

Fig. 13. TEM image of $f c c-\mathrm{ZrPt}_{3}$ (a) and $h c p-\mathrm{ZrPt}_{3}$ (b) nanoparticles and their specific activities for ethanol electro-oxidation (c). Reprinted with permission from Ref. [111]. Copyright 2014, American Chemical Society. the generation of significant amounts of defect sites that facilitated the adsorption and activation of $\mathrm{CO}$ and $\mathrm{O}_{2}$ molecules [113].

\section{Perspective}

In the past three decades, we have experienced and benefited from the impressive impact of size and morphology controlled synthesis of metal nanoparticles. The concept of nanocatalysis not only advanced the development of more efficient catalysts but also deepened fundamental understanding in the structure-performance relationship at the atomic, molecular, and nano scales. The size and morphology effects of metal nanoparticles are generally associated with the variations in electronic properties and geometrical structures. These nanocatalysts are crystallized in the thermodynamically stable phase. For examples, $\mathrm{Ru}, \mathrm{Fe}$, and $\mathrm{Pt}_{3} \mathrm{Co}$ nanoparticles are present as the $h c p, b c c$ and $f c c$ phases, respectively. However, the metastable phases of $f c c-\mathrm{Ru}, f c c$-Fe and $L 1_{2}-\mathrm{Pt}_{3} \mathrm{Co}$ were recently found to be more active for several chemical reactions, primarily due to the changes in electronic properties and coordination environment. This is a newly emerging and growing topic in nanocatalysis. There are several critical issues that should be taken into account when elaborating the effect of the crystal phase of the metal nanoparticles on the catalytic properties. First, the synthetic method for tuning the crystal phase of metal nanoparticles with a specific size and morphology is still empirical. The in-depth study of the synthesis mechanism in liquid solution would enable the simultaneous control of microstructure in terms of chemical composition, size, morphology and crystal phase. More importantly, there would be advances in the fabrication of metal nanoparticles in metastable crystal phases. Second, the phase transition of a metal nanoparticle is usually achieved by thermal treatment at elevated temperatures and under a reactive atmosphere, but this is accompanied with the sintering of nanoparticles or leaching of chemical elements. For example, the phase transformation of $\mathrm{Pt}_{3} \mathrm{Co}$ nanoparticles from disordered $f c c$ to ordered $L 1_{2}$ structure under a hydrogen atmosphere at $973 \mathrm{~K}$ increased the particle size from 4.8 to 7.2 $\mathrm{nm}$ and caused Pt leaching with the formation of a Pt-rich shell [60]. Accordingly, the changes in ORR activity cannot be simply assigned to the crystal phase of the $\mathrm{Pt}_{3} \mathrm{Co}$ particles, and should take the additional size effect and composition change into consideration. Spatial confinement of metal nanoparticles, for example, the construction of core-shell or yolk-shell nanostructures [114-119] and the confinement of metal nanoparticles inside carbon nanotubes [120-125], may be technically applicable for avoiding sintering and leaching of metal nanoparticles during the phase transformation. One promising example is the confinement of $f c c$-Re nanowires $\sim 0.4 \mathrm{~nm}$ wide in the channels of carbon nanotubes that resulted in a stronger interaction to stabilize the metastable $f c c$ phase [126]. Finally, it is necessary to address the structural stability of the metastable crystal phase of metal nanoparticles under reaction conditions. The reaction temperature and atmosphere often induce reconstruction of the catalyst particle and therefore convert the metastable phase into the thermodynamically stable one dur- 
ing the course of catalytic reaction. A detailed structural analysis of working or used catalysts, especially the lattice structure and exposed crystal face, combined with the use of cutting-edge physical and chemical techniques, should be applied for clarifying the crystal phase effect in metal nanoparticles.

Yong Li, Wenjie Shen

State Key Laboratory of Catalysis, Dalian Institute of Chemical Physics, Chinese Academy of Sciences, Dalian 116023, Liaoning, China

Tel: +86-411-82463019, +86-411-84379085

Fax: +86-411-84694447

E-mail: yongli@dicp.ac.cn, shen98@dicp.ac.cn

Received 6 May 2015

Published 20 September 2015

DOI: 10.1016/S1872-2067(15)60932-9

\section{References}

[1] Yu W T, Porosoff M D, Chen J G. Chem Rev, 2012, 112: 5780

[2] Takei T, Akita T, Nakamura I, Fujitani T, Okumura M, Okazaki K, Huang J H, Ishida T, Haruta M. Adv Catal, 2012, 55: 1

[3] Zaera F. ChemSusChem, 2013, 6: 1797

[4] Viñes F, Gomes J R B, Illas F. Chem Soc Rev, 2014, 43: 4922

[5] Dai Y H, Wang Y, Liu B, Yang Y H. Small, 2015, 11: 268

[6] Schlögl R. Angew Chem Int Ed, 2015, 54: 3465

[7] Wu B H, Zheng N F. Nano Today, 2013, 8: 168

[8] Zaera F. Chem Soc Rev, 2013, 42: 2746

[9] Cuenya B R. Acc Chem Res, 2013, 46: 1682

[10] Hutchings G J, Kiely C J. Acc Chem Res, 2013, 46: 1759

[11] Zhang H, Jin M S, Xiong Y J, Lim B, Xia Y N. Acc Chem Res, 2013, 46: 1783

[12] Mahmoud M A, Narayanan R, El-Sayed M A. Acc Chem Res, 2013, 46: 1795

[13] Wu J B, Yang H. Acc Chem Res, 2013, 46: 1848

[14] Porter N S, Wu H, Quan Z W, Fang J Y. Acc Chem Res, 2013, 46: 1867

[15] Li N, Zhao P X, Astruc D. Angew Chem Int Ed, 2014, 53: 1756

[16] Jung N, Chung D Y, Ryu J, Yoo S J, Sung Y E. Nano Today, 2014, 9: 433

[17] Van Hardeveld R, Hartog F. Surf Sci, 1969, 15: 189

[18] Seo D H, Shin H, Kang K, Kim H, Han S S. J Phys Chem Lett, 2014, 5: 1819
[19] Hammer B, Nørskov J K. Adv Catal, 2000, 45: 71

[20] Nørskov J K, Bligaard T, Rossmeisl J, Christensen C H. Nat Chem, 2009, 1: 37

[21] Dinega D P, Bawendi M G. Angew Chem Int Ed, 1999, 38: 1788

[22] Sun S H, Murray C B. J Appl Phys, 1999, 85: 4325

[23] O'Shea V A de la P, Moreira I de P R, Roldán A, Illas F. J Chem Phys, 2010, 133: 024701

[24] Li Y, Liu Q Y, Shen W J. Dalton Trans, 2011, 40: 5811

[25] Ferrando R, Jellinek J, Johnston R L. Chem Rev, 2008, 108: 845

[26] Alloyeau D, Mottet C, Ricolleau C. Nanoalloys: Synthesis, Structure and Properties. London: Springer, 2012.159

[27] Johnston R L, Wilcoxon J P. Metal Nanoparticles and Nanoalloys. Amsterdam: Elsevier, 2012.1

[28] Leiva E P M, Mariscal M M, Oviedo O A. Metal Clusters and Nanoalloys: From Modeling to Applications. New York: Springer, 2013. 29

[29] Singh A K, Xu Q. ChemCatChem, 2013, 5: 652

[30] Notan Francesco I, Fontaine-Vive F, Antoniotti S. ChemCatChem, 2014, 6: 2784

[31] Zhang Z C, Xu B, Wang X. Chem Soc Rev, 2014, 43: 7870

[32] Kim D, Resasco J, Yu Y, Asiri A M, Yang P D. Nat Commun, 2014, 5: 4948

[33] Studt F, Sharafutdinov I, Abild-Pedersen F, Elkjær C F, Hummelshøj J S, Dahl S, Chorkendorff I, Nørskov J K. Nat Chem, 2014, 6: 320

[34] Armbrüster M, Kovnir K, Friedrich M, Teschner D, Wowsnick G, Hahne M, Gille P, Szentmiklósi L, Feuerbacher M, Heggen M, Girgsdies F, Rosenthal D, Schlögl R, Grin Y. Nat Mater, 2012, 11: 690

[35] Holewinski A, Idrobo J C, Linic S. Nat Chem, 2014, 6: 828

[36] Xin H L, Holewinski A, Schweitzer N, Nikolla E, Linic S. Top Catal, 2012, 55: 376

[37] Mun J H, Chang Y H, Shin D O, Yoon J M, Choi D S, Lee K M, Kim J Y, Cha S K, Lee J Y, Jeong J R, Kim Y H, Kim S O. Nano Lett, 2013, 13: 5720

[38] Friedrich M, Villaseca S A, Szentmiklósi L, Teschner D, Armbrüster M. Materials, 2013, 6: 2958

[39] Kitakami O, Sato H, Shimada Y, Sato F, Tanaka M. Phys Rev B, 1997, 56: 13849

[40] Alloyeau D, Ricolleau C, Mottet C, Oikawa T, Langlois C, Le Bouar Y, Braidy N, Loiseau A. Nat Mater, 2009, 8: 940

[41] Watt J, Cheong S, Tilley R D. Nano Today, 2013, 8: 198

[42] Thanh N T K, Maclean N, Mahiddine S. Chem Rev, 2014, 114: 7610

[43] Long R, Zhou S, Wiley B J, Xiong Y J. Chem Soc Rev, 2014, 43: 6288

[44] Min Y, Kwak J, Soon A, Jeong U. Acc Chem Res, 2014, 47: 2887

\section{Graphical Abstract}

Chin. J. Catal., 2015, 36: 1409-1418 doi: 10.1016/S1872-2067(15)60932-9

Tuning the catalytic behavior of metal nanoparticles: The issue of the crystal phase

Shuang Liu, Yong Li*, Wenjie Shen*

Dalian Institute of Chemical Physics, Chinese Academy of Sciences

The impact of the crystal phase of metal nanoparticles on catalytic performance was reviewed. This is a new direction for nanocatalysts.

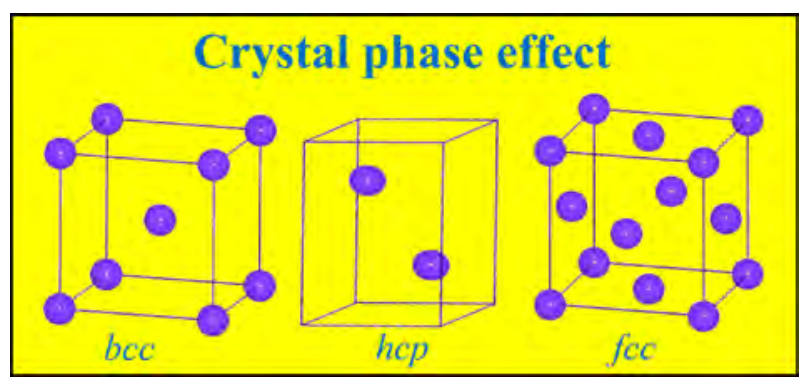


[45] Yu Y, Zhang Q B, Yao Q F, Xie J P, Lee J Y. Acc Chem Res, 2014, 47: 3530

[46] Wu Y E, Wang D S, Li Y D. Chem Soc Rev, 2014, 43: 2112

[47] Wang Y W, He J T, Liu C C, Chong W H, Chen H Y. Angew Chem Int $E d, 2015,54: 2022$

[48] Kusada K, Kobayashi H, Yamamoto T, Matsumura S, Sumi N, Sato K, Nagaoka K, Kubota Y, Kitagawa H. J Am Chem Soc, 2013, 135: 5493

[49] Abo-Hamed E K, Pennycook T, Vaynzof Y, Toprakcioglu C, Koutsioubas A, Scherman O A. Small, 2014, 10: 3145

[50] Yang Z J, Yang N L, Yang J H, Bergström J, Pileni M P. Adv Funct Mater, 2015, 25: 891

[51] Halder A, Kundu P, Viswanath B, Ravishankar N. J Mater Chem, 2010, 20: 4763

[52] Shen S L, Wang X. Chem Commun, 2010, 46: 6891

[53] Gong M G, Kirkeminde A, Skomski R, Cui J, Ren S Q. Small, 2014, 10: 4118

[54] Gong M G, Kirkeminde A, Wuttig M, Ren S Q. Nano Lett, 2014, 14: 6493

[55] Goltsov V A. J Alloy Comp, 1999, 293-295: 844

[56] Pundt A, Kirchheim R. Annu Rev Mater Res, 2006, 36: 555

[57] Carenco S. Chem Eur J, 2014, 20: 10616

[58] Yamauchi M, Okubo K, Tsukuda, T, Kato K, Takata M, Takeda S. Nanoscale, 2014, 6: 4067

[59] Kuttiyiel K A, Sasaki K, Su D, Wu L J, Zhu Y M, Adzic R R. Nat Commun, 2014, 5: 5185

[60] Wang D L, Xin H L L, Hovden R, Wang H S, Yu Y C, Muller D A, Di Salvo F J, Abruña H D. Nat Mater, 2013, 12: 81

[61] Karaca H, Safonova O V, Chambrey S, Fongarland P, Roussel P, Griboval-Constant A, Lacroix M, Khodakov A Y.J Catal, 2011, 277: 14

[62] Sadeqzadeh M, Karaca H, Safonova O V, Fongarland P, Chambrey S, Roussel P, Griboval-Constant A, Lacroix M, Curulla-Ferré D, Luck F, Khodakov A Y. Catal Today, 2011, 164: 62

[63] Iglesia E. Appl Catal A, 1997, 161: 59

[64] Khodakov A Y, Chu W, Fongarland P. Chem Rev, 2007, 107: 1692

[65] Zhang Q H, Kang J C, Wang Y. ChemCatChem, 2010, 2: 1030

[66] van Santen R A, Markvoort A J, Filot I A W, Ghouri M M, Hensen E J M. Phys Chem Chem Phys, 2013, 15: 17038

[67] Bezemer G L, Bitter J H, Kuipers H P C E, Oosterbeek H, Holewijn J E, Xu X D, Kapteijn F, van Dillen A J, de Jong K P. J Am Chem Soc, 2006, 128: 3956

[68] den Breejen J P, Radstake P B, Bezemer G L, Bitter J H, Frøseth V, Holmen A, de Jong K P. J Am Chem Soc, 2009, 131: 7197

[69] Geerlings J J C, Zonnevylle M C, de Groot C P M. Surf Sci, 1991, 241: 315

[70] Kwak G, Woo M H, Kang S C, Park H G, Lee Y J, Jun K W, Ha K S. J Catal, 2013, 307: 27

[71] Enache D I, Rebours B, Roy-Auberger M, Revel R. J Catal, 2002, 205: 346

[72] Gnanamani M K, Jacobs G, Shafer W D, Davis B H. Catal Today, 2013, 215: 13

[73] Li B H, Zhang Q J, Chen L, Cui P, Pan X Q. Phys Chem Chem Phys, 2010, 12: 7848

[74] Liu J X, Su H Y, Sun D P, Zhang B Y, Li W X. J Am Chem Soc, 2013, 135: 16284

[75] van Santen R A. Acc Chem Res, 2009, 42: 57

[76] Shetty S G, Ciobîcă I M, Hensen E J M, van Santen R A. Chem Commun, 2011, 47: 9822

[77] Corral Valero M, Raybaud P. Catal Lett, 2013, 143: 1

[78] Prieto G, Concepción P, Murciano R, Martínez A. J Catal, 2013, 302 37
[79] Ciobîcă I M, van Santen R A, van Berge P J, van de Loosdrecht J. Surf Sci, 2008, 602: 17

[80] Cheng J, Hu P, Ellis P, French S, Kelly G, Lok C M. J Phys Chem C, 2010, 114: 1085

[81] Ge Q F, Neurock M.J Phys Chem B, 2006, 110: 15368

[82] Lv Y G, Li Y, Shen W J. Catal Commun, 2013, 42: 116

[83] Yang Z J, Yang J H, Bergström J, Khazen K, Pileni M P. Phys Chem Chem Phys, 2014,16: 9791

[84] Ertl G. Angew Chem Int Ed, 2008, 47: 3524

[85] Galvis H M T, de Jong K P. ACS Catal, 2013, 3: 2130

[86] Grüne M, Radnik J, Wandelt K. Surf Sci, 1998, 402-404: 236

[87] Radnik J, Chopovskaya E, Grüne M, Wandelt K. Surf Sci, 1996, 352-354: 268

[88] Tanabe T, Kubo K, Ishibashi T, Wadayama T, Hatta A. Appl Surf Sci, 2003, 207: 115

[89] Honkala K, Hellman A, Remediakis I N, Logadottir A, Carlsson A, Dahl S, Christensen C H, Nørskov J K. Science, 2005, 307: 555

[90] Liu H Z. Chin J Catal (刘化章. 催化学报), 2014, 35: 1619

[91] Foppa L, Dupont J. Chem Soc Rev, 2015, 44: 1886

[92] Zhang Q H, Cheng K, Kang J C, Deng W P, Wang Y. ChemSusChem, 2014, 7: 1251

[93] Over H. Chem Rev, 2012, 112: 3356

[94] Watanabe S, Komine T, Kai T, Shiiki K. J Magnet Magnet Mater, 2000, 220: 277

[95] Over H, Kim Y D, Seitsonen A P, Wendt S, Lundgren E, Schmid M, Varga P, Morgante A, Ertl G. Science, 2000, 287: 1474

[96] Joo S H, Park J Y, Renzas J R, Butcher D R, Huang W Y, Somorjai G A. Nano Lett, 2010, 10: 2709

[97] Ma H Y, Na C Z. ACS Catal, 2015, 5: 1726

[98] Yamauchi M, Kobayashi H, Kitagawa H. ChemPhysChem, 2009, 10: 2566

[99] Li G Q, Kobayashi H, Dekura S, Ikeda R, Kubota Y, Kato K, Takata M, Yamamoto T, Matsumura S, Kitagawa H. J Am Chem Soc, 2014, 136: 10222

[100] Li G Q Kobayashi H, Taylor J M, Ikeda R, Kubota Y, Kato K, Takata M, Yamamoto T, Toh S, Matsumura S, Kitagawa H. Nat Mater, 2014, 13: 802

[101] Wadell C, Syrenova S, Langhammer C. ACS Nano, 2014, 8: 11925

[102] Baldi A, Narayan T C, Koh A L, Dionne J A. Nat Mater, 2014, 13: 1143

[103] Bardhan R, Hedges L O, Pint C L, Javey A, Whitelam S, Urban J J. Nat Mater, 2013, 12: 905

[104] Teschner D, Borsodi J, Wootsch A, Révay Z, Hävecker M, Knop-Gericke A, Jackson S D, Schlögl R. Science, 2008, 320: 86

[105] Armbrüster M, Behrens M, Cinquini F, Föttinger K, Grin $Y$, Haghofer A, Klötzer B, Knop-Gericke A, Lorenz H, Ota A, Penner S, Prinz J, Rameshan C, Révay Z, Rosenthal D, Rupprechter G, Sautet P, Schlögl R, Shao L D, Szentmiklósi L, Teschner D, Torres D, Wagner R, Widmer R, Wowsnick G. ChemCatChem, 2012, 4: 1048

[106] Mendez C M, Olivero H, Damiani D E, Volpe M A. Appl Catal B, 2008, 84: 156

[107] Vít Z, Gulková D, Kaluža L, Boaro M. Appl Catal B, 2014, 146: 213

[108] Aleksandrov H A, Kozlov S M, Schauermann S, Vayssilov G N, Neyman K M. Angew Chem Int Ed, 2014, 53: 13371

[109] Zhang S, Zhang X, Jiang G M, Zhu H Y, Guo S J, Su D, Lu G, Sun S H. J Am Chem Soc, 2014, 136: 7734

[110] Erini N, Loukrakpam R, Petkov V, Baranova E A, Yang R Z, Teschner D, Huang Y H, Brankovic S R, Strasser P. ACS Catal, 2014, 4: 1859

[111] Ramesh G V, Kodiyath R, Tanabe T, Manikandan M, Fujita T, Umezawa N, Ueda S, Ishihara S, Ariga K, Abe H. ACS Appl Mater 
Interf, 2014, 6: 16124

[112] Sarkar S, Balisetty L, Shanbogh P P, Peter S C. J Catal, 2014, 318 : 143

[113] Kusada K, Kobayashi H, Ikeda R, Kubota Y, Takata M, Toh S, Yamamoto T, Matsumura S, Sumi N, Sato K, Nagaoka K, Kitagawa H. J Am Chem Soc, 2014, 136: 1864

[114] Chaudhuri R G, Paria S. Chem Rev, 2012, 112: 2373

[115] Mitsudome T, Kaneda K. ChemCatChem, 2013, 5: 1681

[116] Li G D, Tang Z Y. Nanoscale, 2014, 6: 3995

[117] Hu P, Morabito J V, Tsung C K. ACS Catal, 2014, 4: 4409

[118] Priebe M, Fromm K M. Chem Eur J, 2015, 21: 3854
[119] Sun Q Zhang X Q, Wang Y, Lu A H. Chin J Catal (孙葍, 张向倩, 王 阳, 陆安慧. 催化学报), 2015, 36: 683

[120] Pan X L, Bao X H. Acc Chem Res, 2011, 44: 553

[121] Su D S, Perathoner S, Centi G. Chem Rev, 2013, 113: 5782

[122] Ding M N, Tang Y F, Star A.J Phys Chem Lett, 2013, 4: 147

[123] Zhu J, Holmen A, Chen D. ChemCatChem, 2013, 5: 378

[124] Xiong H F, Jewell L L, Coville N J. ACS Catal, 2015, 5: 2640

[125] Matthiesen J, Hoff T, Liu C, Pueschel C, Rao R, Tessonnier J P. Chin J Catal (催化学报), 2014, 35: 842

[126] Zhang F, Ren P J, Pan X L, Liu J Y, Li M R, Bao X H. Chem Mater, 2015, 27: 1569

\section{晶相调控对金属纳米粒子催化性能的影响}

刘爽，李 勇，申文杰*

中国科学院大连化学物理研究所, 催化基础国家重点实验室, 辽宁大连 116023

摘要: 尺寸在1-10 nm的金属纳米催化剂广泛地应用于石油化工, 精细化学品合成, 能源与环境保护等领域. 大量研究表明, 金属 纳米粒子的催化性能与其微观结构, 即尺寸、形貌和晶相等密切相关. 近年来, 对金属纳米粒子的尺寸和形貌效应已经有了较为 系统深入的研究, 但对晶相效应的研究则较少涉及. 这主要是由于介稳晶相的金属纳米粒子在合成过程中或反应条件下极易转 化为热力学稳定的晶相结构. 根据金属原子密堆积形式, 金属纳米粒子的晶相结构主要有立方面心 $(f c c)$ 、立方体心 $(b c c)$ 和六方密 堆积 $(h c p)$ 三种晶相; 而金属合金由于 $d$ 带电子存在着多种杂化方式, 因而其晶相结构呈现出多样性且与单一金属有很大的不同. 金属和合金纳米粒子晶相结构的调控, 不仅会改变金属原子的配位环境, 调控了其电子分布状态, 还可影响反应物和产物的吸附、 活化和脱附, 进而调变催化性能.

首先, 我们简要总结了液相合成和固相转变调控金属纳米粒子晶相的原理和方法. 纳米粒子的液相合成一般包括前驱体还 原成核和晶核生长两个阶段, 通过对液相合成条件的优化, 尤其是表面活性剂的选择, 可有效调控合成过程中的热力学和动力学 因素, 从而实现金属晶相的可控合成. 固相转变则主要是对具有一定晶相结构的纳米粒子于一定气氛和温度条件下进行加热处 理, 利用金属粒子与活性气体之间 $\left(\mathrm{H}_{2}, \mathrm{CO}\right.$ 等) 的化学作用来实现晶相转变. 利用上述方法, 可以合成出 $f c c-\mathrm{Co} 、 f c c-\mathrm{Ru} 、 L 1_{0}-\mathrm{AuCu}$ 等热力学介稳的金属或合金纳米粒子.

在此基础之上, 我们分别以 $\mathrm{Co}$ 纳米粒子( $f c c$ 和 $h c p$ 晶相)催化 $\mathrm{FT}$ 合成, $\mathrm{Fe}$ 模型催化剂( $f c c$ 和 $b c c$ 晶相)活化 $\mathrm{N}_{2}$ 和 $\mathrm{CO}, \mathrm{Ru}$ 纳米粒子 ( $f c c$ 和 $h c p$ 晶相) 催化 $\mathrm{CO}$ 氧化和氨硼烷水解制氢, $\mathrm{Pd}$ 纳米粒子( $\mathrm{PdH} x$ 物种) 催化加氢等为例分析了晶相对金属纳米粒子催化性能的影 响; 在合金催化剂方面, 以 $\mathrm{Pt}_{3} \mathrm{Co}$ (无序的 $f c c$ 和有序的 $\left.L 1_{2}\right), \operatorname{AuPdCo}\left(P 3 m 、 F m \overline{3} m\right.$ 和 $R \overline{3} m$ 混合晶相)和 $\mathrm{FePt}$ 纳米粒子 $\left(f c c\right.$ 和 $f c t$ 相)催化 $\mathrm{O}_{2}$ 电化学还原、 $\mathrm{PtRhSn}$ (碲铂矿晶相和 $f c c$ 晶相)和 $\mathrm{ZrPt}_{3}$ 纳米粒子 ( $h c p$ 和 $f c c$ 晶相) 催化乙醇电氧化、 $\mathrm{Ag}_{3} \mathrm{In}$ 合金(无序的 $F m \overline{3} m$ 相和有序 的 $P m \overline{3} m$ 晶相)催化对硝基苯酚加氢、 $\mathrm{PdRu}$ 纳米粒子( $f c c$ 和 $h c p$ 混合晶相)催化 $\mathrm{CO}$ 氧化等为例分析了合金催化剂的晶相对催化性能 的影响. 上述研究进展表明, 金属纳米粒子的晶相也是影响制备剂高效金属催化剂的主要因素.

最后, 我们结合纳米催化的发展现状, 提出了金属纳米粒子的晶相调控在纳米催化和纳米材料领域可能的发展态势. 第一, 通过对金属纳米粒子溶液相合成机理的深入研究, 有助于发展出尺寸、形貌和晶相同时可控的新合成方法. 第二, 金属纳米粒子 在晶相转化过程中往往伴随着烧结及组分的偏析等难题. 利用氧化物包覆的核壳型或蛋壳型纳米结构以及碳纳米管的空间限域 效应, 或许有助于解决上述难题. 第三, 具有亚稳晶相结构的金属纳米粒子在反应条件下极易转变为热力学稳定的结构, 因此, 利 用原位、动态、实时的表征技术对催化剂在真实工作状态下的微观结构进行细致的分析是阐明晶相效应的前提.

关键词: 金属纳米粒子; 纳米合金; 晶相结构; 纳米催化剂; 构效关系

收稿日期: 2015-05-06. 接受日期: 2015-06-12. 出版日期: 2015-09-20.

*通讯联系人. 电话: (0411)84379085; 传真: (0411)84694447; 电子信箱: shen98@dicp.ac.cn

\#通讯联系人. 电话: (0411)82463019; 传真: (0411)84694447; 电子信箱: yongli@dicp.ac.cn 基金来源: 国家自然科学基金(21025312, 21003118, 21373205); 国家重点基础研究发展计划(973计划, 2013CB933100).

本文的英文电子版由Elsevier出版社在ScienceDirect上出版(http://www.sciencedirect.com/science/journal/18722067). 